\title{
Legal Thinking in the Interwar Latvian Senate
}

\author{
Dr. iur. Diāna Apse \\ Faculty of Law, University of Latvia \\ Department of Theory and History of Law \\ Docent \\ E-mail: diana.apse@lu.Iv
}

In this article, the author researches and analyses the legal thinking created by Senators A. Lēbers and M. Čakste, aspects of interdisciplinary interaction of subsidiary sources and branches of law in the interwar Latvian Senate. The findings made by the senators of interwar Latvia (in the capacity of rapporteurs on a case, members of the court's composition) help to explore the historical events and the legal culture of the respective age by reading the primary sources. In the conditions of contemporary legal system, the described cases and legal institutions mostly have similar regulation and could be useful for the development of the case law on the respective matter. Interaction of subsidiary sources, in particular, the used findings of the doctrine build bridges across ages and promote the continuity of uniform case law and understanding of law. The range of resolved legal matters pertained to a broad area of law - branches of law, interdisciplinary aspects of the legal system. The scientific contribution by Senators A. Lèbers and M. Čakste is universal and significant in the context of European and global thinking. Notwithstanding the circumstances, they remained loyal to democratic Latvia.

Keywords: legal system, legal sources, legal science, case law, continuity, legal thinking.

\section{Contents}

Introduction . . . . . . . . . . . . . . . . . . . . . . . . . . . . . . . 224

1. Aspect of Succession in Legal Thinking and Subsidiary Sources of Law . . . . . . . . . . 225

2. Some Aspects in the Interaction Between the Personality and Legal Thinking

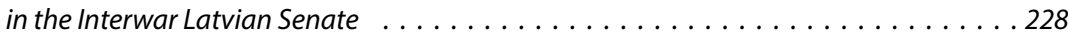

2.1. Reports by Senator A. Loeber . . . . . . . . . . . . . . . . . . . . . . . . 229

2.2. Reports by Senator M. Čakste . . . . . . . . . . . . . . . . . . . 233

Summary. . . . . . . . . . . . . . . . . . . . . . . . . . 238

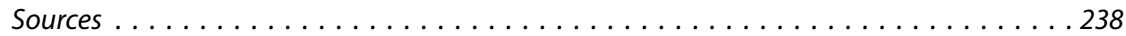

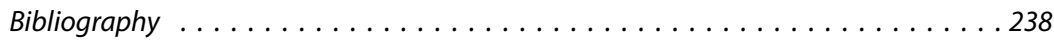

Other Sources . . . . . . . . . . . . . . . . . . . . . . . . . . . . . . 240 


\section{Introduction}

After the independence of the Latvian state was restored, the Latvian legal system reintegrated into the Western circle of law (more specifically - the family of continental European law), returning to the system of sources and subsidiary sources of law, typical of it, in which the court rulings and judges' findings occupy a special place. Scholars of law have repeatedly urged to use the findings of the legal science and case law of the interwar Latvia, in particular, those of the Senate.

The legal system of each state is created by scholars of law, who define the spirit, values and the vector of development of this system. Outstanding lawyers cared for the continuity of this vector, taking a stance against unfair law, unlawful situations, which were incompatible with the basic values of the legal system of a democratic state governed by the rule of law.

Pursuant to Article 16 of the law "On Judicial Power", court judgements have the force of law. This formulation, taken together with the findings of legal science, allows classifying the place of a court's judgement among the sources of law as even the supreme form of customary law.

All well-reasoned and methodologically correctly created judgements point to the significance of the judge's previous experience in shaping legal thinking and understanding of legal interconnections, underscoring that the legal issues keep recurring and answers have been provided to them already.

Law originates as the outcome of practice. A court's ruling, as a form of customary law, impacts, supplements and even creates law. Simultaneously, all factors, which the judge has involved in the creation, development or adjustment of law and has used to substantiate his reasoning and conclusions, also take a significant place in the diversity of legal sources, constituting the entire legal system.

However, constant case law rather than separate cases is of decisive importance. To ensure that the principle of equality, enshrined in Article 91 of the Satversme, is complied with and to prevent different legal effects, a judge, in adjudicating a particular case, must take into consideration also the existing case law on this matter. Assessment of similar cases helps to interpret the applicable legal norms correctly.

In the context of the continuity doctrine, studying the Latvian Senate's judgements and identification of the findings expressed therein, assessing the possibilities of applying them in the contemporary practice, is important for implementing the principle of unity and succession of the legal system in the State of Latvia, restored in 1990/1991. The need for the interpretation of legal norms by the Latvian Senate as the supreme institution of judicial power today is substantiated by the validity of several laws adopted in the interwar period (inter alia, the Satversme of 1922). ${ }^{1}$ Perhaps the article will be more useful from the theoretical vantage point, in particular, in the context of the Latvian history of law and theory of law, an also as a source of reference for students and other interested parties.

For example, Civillikums, Zemesgrāmatu likums, Vekseḷu likums [Civil Law, Land Register Law, Bill of Exchange Law] etc. 


\section{Aspect of Succession in Legal Thinking and Subsidiary Sources of Law}

The model for applying the principle of succession in law and case law is the Latvian Senate itself, with many outstanding personalities serving on it, many among them were simultaneously theoreticians and practitioners, making extensive use of findings from subsidiary sources in the reasoning of their judgements. Thus, for example, in examining 1518 judgements of the Administrative Department from the period of 1918-1940 and assessing their impact on law making, special attention should be paid to references to the former case law. They prove that the Senate was influenced by the case law of related legal systems, which could be significant also for the contemporary case law. ${ }^{2}$

However, with respect to the case law, the actual functioning of the succession principle is possible only if the rulings by the Latvian Senate are publicly available and used both by courts and scholars of law in their research.

The research and work implemented by Prof. Dietrich André Loeber greatly contributed to studying the role of the Latvian Senate following the restoration of the state's sovereignty. They prove, inter alia, that the quality of the Latvian Senate's rulings was highly esteemed also abroad. Several of them had been translated and popularised among lawyers in other countries. These rulings had a significant impact on the quality of rulings delivered by lower instance courts.

Prior to occupation, Latvia was clearly aware of the importance of unified case law. Judgements by the Assembly of the Latvian Senate, as well as judgements and decisions by the Senate's departments were systematically published. ${ }^{3}$ Thanks to D. A. Loeber, a large part of these rulings was re-published in 1997-1998, in 16 volumes, with additional 3 volumes of indices, prepared by the professor, ${ }^{4}$ and now they are available at major libraries and judicial institutions.

Currently, a large part of the texts of the Latvian Senate's rulings is available also on the homepage of the Law Research Institute ${ }^{5}$ and the homepage of the Supreme Court (Senate) ${ }^{6}$, regularly supplemented with rulings that have been used in administering justice.

The current case law proves that the Senate's findings are used both in administering justice and in the development of legal doctrine, inter alia, in interpreting those provisions of the Civil Law, which are in force in their original wording of 1937. However, in general, knowledge of the importance of the Latvian Senate's rulings and skills for using them in practice are insufficient among the extensive contemporary community of lawyers. Examples from case law also show that the significance of the former case law continues to be undervalued.

2 See more: Apse, D. Tiesu prakse un Latvijas Senāta Administratīvais departaments (1918-1940) [Judicial practice and the Administrative Department of the Latvian Senate (1918-1940)]. In: Tiesu prakses veidošana. LU Raksti [Development of court practice. LU scientific articles]. Edited by Dr. habil. iur. prof. Melksisis, E. Rīga: Latvijas Universitāte, 2001, pp. 68-101.

3 Ibid., p. 10.

4 Latvijas Senāta spriedumi (1918-1940). Faksimilizdevums [Judgments of the Latvian Senate (19181940). Facsimile edition]. Riga: Supreme Court of the Republic of Latvia, Senator August Loeber Foundation, 1997-1998; Rādītāji Latvijas Senāta spriedumu krājumiem [Indicators for the collections of judgments of the Latvian Senate]. Edited by Loeber, D. A, Rìga: D. A. Lēbers, 1997.

5 Tiesību zinātṇu pētniecības institūts [Law Research Institute]. Available: https://tzpi.lu.lv/pirmaisneatkaribas-laiks/tiesu-prakse/ [last viewed 18.02.2021].

6 Augstākā tiesa. Vēsturiskā judikatūra [Supreme Court. Historical case law]. Available: http://at.gov.lv/ lv/judikatura/vesturiska-judikatura-lidz-1940gadam [last viewed 18.02.2021]. 
Underscoring the importance of legal science in civil law relations both in explaining legal norms and in resolving particular civil law disputes, professor $\mathrm{K}$. Torgāns has noted, inter alia: "As is well-known, the foundation of the civil law regulation since 1992 is the reinstated Latvian Civil Law of 1937. It was drawn up by men who knew the traditions of the European legal acts and law. [..] However, in the years that have passed since the reinstatement of the Civil Law, it has become apparent that in contemporary society norms that are defined generally, and legal norms should be like that, in the contractual practice and in courts may be interpreted in a way that the fathers of the Civil Law could not even dream of." Therefore, the historical findings, included in the rulings by the Latvian Senate, have special significance in identifying the genuine content and aim of the provisions of the Civil Law. The value of these findings in the resolution of current legal disputes is proven by the list, found in Annex 5 to the first part of the book "The Bureau of the Latvian Senate's Judgements. Findings of the Latvian Senate on the Application of the Civil Law Provisions (1938-1940)", of those rulings by the Department of Civil Cases of the Supreme Court (Senate), in which the court has referred to particular rulings of the Latvian Senate. In this, the principles of unity of the legal system and succession in law are manifested in reality.

Moral obligation, demanded by law, does not turn into the legal reality on its own. The one who applies the norm, the judge, stands between the moral obligation and the reality. How the abstract "moral obligation" turns into the particular legal reality depends on his professional knowledge and skills, understanding of law and social processes, culture, mental outlook, civil position, and other factors. ${ }^{8}$

A judge and a scholar of law, in developing their reasoning, must have also high level of internal normative ethics and scientific thinking. This is also a matter of the level of legal education.

At the time of forming the Department of Legal Science of the Faculty of Economics and Law of the Higher School of Latvia, the majority of the faculty members had acquired their legal education at the universities of the Russian Empire in Petersburg, Moscow, Dorpat, and Kazan. Some had had in-service training also in West European countries, for example, August Loeber, the first acting dean, who taught introduction to law.

Therefore, in creating the system of theoretical lectures at the Department of Law, the model of former Russian faculties of law was followed, while the model of German and French law faculties was used for the practical seminars. ${ }^{9}$

In moments when the fate of the Latvian state has turned, people of other nationalities, whose motherland is Latvia and who consider themselves as being affiliated with Latvia, have been together with the Latvian people. This has been

Torgāns, $K$. Tiesību principu, likumu un zinātnes atziṇu loma civiltiesisku strīdu risināšanā [The Role of Legal Principles, Laws and Scientific Findings in Resolving Civil Disputes]. Jurista Vārds, No. 49, 04.12.2018, p. 13.

8 Melkisisis, E. Attīstības tendences dažos tiesību teorijas un prakses jautājumos. Par precedentu un tiesu prakses veidošanu. Latvijas tiesiskās sistēmas ceḷ̌s uz demokrātisku tiesisku valsti. Rakstu krājums [Development tendencies in some issues of legal theory and practice. On the formation of precedents and case law. The path of the Latvian legal system to a democratic state governed by the rule of law. Collection of articles]. Rīga: Tiesu namu agentūra, 2014, p. 164.

9 Dišlers, K., Dunsdorfs, E. Tautsaimniecības un tiesību zinātṇu fakultāte [Faculty of Economics and Law]. In: Latvijas Universitāte divdesmit gados. 1919-1939. I daḷa. Vēsturiskas un statistiskas ziņas par Universitāti un tās fakultātēm [University of Latvia in twenty years. 1919-1939. Part I. Historical and statistical information about the University and its faculties]. Riga: Latvijas Universitāte, 1939, p. 748 . 
vividly proven by the work done and attitude taken by the Baltic German scholars of law - professor and senator August Loeber and his son professor Dietrich André Loeber. ${ }^{10}$ Already since 17 April 1920, soon after the University of Latvia was established, August Loeber was the first non-Latvian faculty member who started lecturing to students of the Department of Law in the official language of the state... Probably, such traditions, such attitude can develop only in a family with ancient and deep roots in the Latvian soil. From the day when independent Latvia was proclaimed, August Loeber became actively involved in building the new state. Being a mature practicing lawyer and a theoretician, he could contribute a lot. A. Loeber, invited by the Minister for Justice, participates in creating the supreme judicial institution of Latvia, i.e., the Senate, and becomes one of the first senators. He served in this office for 20 years (1918-1938). Later he was elected Honorary Judge of the Senate. In 1919, A. Loeber together with future President of Latvia docent J. Čakste, docent K. Puriņš and docent A. Hēdenštrēms established the Law and Economics Faculty (Faculty of Economic and Legal Science) at the University of Latvia and was the acting dean of this faculty. As of 1931, he also was a professor and taught introduction to law and trade law. In 1930, the University of Latvia conferred upon August Loeber the honorary degree Doctor iuris honoris causa. In 1935, after reaching the age of 70, Prof. A. Loeber retired from the University, continuing to work only in the Senate. ${ }^{11}$

Later, graduates of the faculty joined the ranks of lecturers. The first one was Pēteris Mucenieks, who graduated from the faculty in 1923 and in 1925 was elected to the position of an assistant ${ }^{12}$. In the coming years, Konstantins Čakste (Civil Law Department), Lotārs Šulcs (Criminal Law Department), Jānis Vālbergs (Department of Latvian State Law), Voldemārs Kalniņš (Roman Law Department), Pēteris Lejiņš (Criminal Law Department), Beno Ābers (Department of History of Law) and others joined the faculty. ${ }^{13}$

In the Latvian practice of administering justice, the use of previous decisions and judgements by higher instance courts, which had entered into effect, in similar cases traditionally has become a consolidated practice in Latvia. Research of how (subsidiary) sources of law were used in 1938, when the new Civil Law had entered into force, revealed that 324 decisions by the Senate's Departments comprised 169 references to particular previous court decisions. Likewise, case law was extensively used in commentaries on laws, illustrating the diversity in the application of

10 Apsitis, R. Par Latvijas pamatu vïriem. Runas. Raksti. Referāti [About Men at Latvia’s Foundations. Speeches. Writings. Reports]. Latvijas Vēstnesis, No. 11/12, 16.01.1998. Available: https://www. vestnesis.lv/ta/id/31202 [last viewed 20.02.2021].

"In the autumn of 1939, the Loeber's family, like other German-Baltics, left Latvia at the invitation of the then German government."

11 "Senator A. Leber was one of the drafters of the Latvian Civil Law of 1937, also a co-author of several other laws. He has made a great contribution to the unification of check and bill of exchange law in the Baltic states. It is also to his credit that in 1938 the same bill of exchange and check law was passed in Latvia, Lithuania and Estonia. A. Leber has written a lot of works on Latvian legal issues. In 1926, he published a 483-page "Report on Commercial Law", which was useful for both students and lawyers-practitioners for many years." Ibid.

12 Latvijas Universitāte divdesmit gados. 1919-1939. II daḷa. Mācības spēku biogrāfijas un bibliogrāija [University of Latvia in twenty years. 1919-1939. II part. Biographies and bibliography of teaching staff]. Rīga: Latvijas Universitāte, 1939, p. 550.

13 Latvijas Universitāte divdesmit gados. 1919-1939. I daḷa. Vēsturiskas un statistiskas ziṇas par Universitāti un tās fakultātēm [University of Latvia in twenty years. 1919-1939. Part I. Historical and statistical information about the University and its faculties]. Riga: Latvijas Universitāte, 1939, pp. $749-750$. 
provisions and fostering the development of uniform practice. ${ }^{14}$ Judgements also contained numerous references to findings made by local and foreign scholars of law and of the case law with respect to similar legal issues. Thus, the findings made in Latvia's "lawyers' law" (theory and practice) transcended the area of its legal system.

\section{Some Aspects in the Interaction Between the Personality and Legal Thinking in the Interwar Latvian Senate}

The role of senators' personalities in the development of legal thinking cannot be overestimated. Examination of only a small part of the legal contribution made by Senators A. Loeber and M. Čakste shows that they meticulously outlined the legal issue in connection with the previous legal reasoning in using legal practice and findings from the doctrine, drew attention to legal uncertainty, previous unfair solutions to a legal matter.

Chronological examination of only some judgements allows to establish the full maturity of legal thinking, its saturation with approach of contemporary legal methodology.

There are examples in the case law of the interwar Latvian Senate demonstrating the application of general legal principles, where the reasoning of the judgements comprised references not only to the legal science but also directly to the general legal principles, e.g., judgement of 8 December 1921 by the Department of Civil Cassation of the Latvian Senate in the case of insurance company "Rossija" 1, No. 188 (request made by sworn advocate A. Zëbergs to revoke the decision by the Court Chamber regarding the request by the Insurance Department of the Ministry of the Interior to appoint a curator in charge of the property of the insurance association "Rossija") and not recognising the legality of the Soviet Russia's decree in Latvia (liquidation of insurance associations was not binding) because that would be contrary to Latvia's public order and laws:

"Latvia as a state governed by the rule of law can recognise as lawful and binding only such orders of a foreign state that comply with the general accepted principles of a legal order, with which the liquidation, in principle, of all insurance associations is incompatible...". 15

The manifestations of the impact of the legal theory and case law of Czarist Russia, the use of findings made therein can be explained by the similar legal systems and their affiliation with the West European circle of law - the traditions of Romano-German law. The findings were not taken over mechanically. They were critically examined and meticulously reviewed in the light of the principle of a state governed by the rule of law.

14 Mel̦kisis, E. Attīstības tendences dažos tiesību teorijas un prakses jautājumos. Par precedentu un tiesu prakses veidošanu. Latvijas tiesiskās sistēmas ceḷš uz demokrātisku tiesisku valsti. Rakstu krājums [Development tendencies in some issues of legal theory and practice. On the formation of precedents and case law. The path of the Latvian legal system to a democratic state governed by the rule of law. Collection of articles]. Rīga: Tiesu namu aǵentūra, 2014, p. 161.

15 Latvijas Senāta Civilā kasācijas departamenta 1921. gada 8. decembra spriedums lietā Nr. 188 [Judgment of the Civil Cassation Department of the Latvian Senate of 8 December 1921 in case No. 188]. In: Konradi, F., Valters, A. Izvilkums no Latvijas Senāta Civilā kasācijas departamenta spriedumiem. 1919.-1925. gada jūlijs. II izdevums [Extract from the Judgment of the Department of Civil Cassation of the Latvian Senate. July 1919-1925. Edition II]. Latvian National Archives, Latvian State Historical Archive (hereafter - LNA LSHA), 1535. fonds [fund] (hereafter - f.), p. 142. Available: http://at.gov.lv/lv/tiesu-prakse/vesturiska-judikatura-lidz-1940gadam/senata-civila-kasacijasdepartamenta-spriedumi [last viewed 18.02.2021]. 
Emphasising the content of the basic principles of the rule-of-law state, Jannis Akuraters, poet, educator, rebel of 1905, participant of the Christmas Battles, in the summer of 1920, in his essay highlighted the substance of the State of Latvia (nature of a state governed by the rule of law), its national culture as the foundation and meaning, which was more important than "the supreme parochial philosophy" of provincialism. ${ }^{16}$

"The modern state may not know harsh measures of governance. The content of the modern state may not hold the old yeast. Search for content, content, the blood of freedom fighters and soldiers mixed with the seething spirit filled with dreams, with what gives new inspiration and new findings... The pure form of the Latvian State could bear only the content of culture. The leaders of our State just have to take the best of the best, they are the bearers of their age, filled with its thirst, democratism and glittering findings of the new world. There is no other way, Latvia can be only modern, filled with European humanism and cultural ideas. Nothing from that which has collapsed, from the ideas of Asian slavery may cast shadow upon us." 17

\subsection{Reports by Senator A. Loeber}

In examination of separate judgements, the presence of global legal thinking and legal methodology can be found in the reasoning thereof.

Within the framework of one succession law dispute, international law, civil law and the findings made by outstanding scholars of law of their age "meet".

Judgement by the Senate's Department of Civil Cassation of 24 October 1929. Request by Andrejs Rancāns, Meikulis Ludboržs and Antons Veliks, guardians of the property of deceased Taduls Rancāns, regarding revoking the judgement by the Court Chamber on the claim by Jadviga Rancāns regarding the entirety of the estate.

(Case number L. JMg 418.) The hearing was chaired by Senator K. Ozolin̄š, with Senator A. Loeber reporting. In view of the fact: 1) that the defendant does not deny that the territory of Zaļmuiža civil parish, where the testator had lived and where the plaintiff lives, falls within the boundaries of Latgale and had been liberated by the Latvian armed forces from the Bolshevik power only in mid-January 2020 and that only afterwards Latvian courts started functioning in the said territory; 2) that, contrary to the defendant's opinion, until that time the said territory had never been considered as a foreign territory; as correctly noted by the Court Chamber and not denied by the defendant, Latvia in its Proclamation of Independence of 18 November 1918 (collection of laws JMy 1.) strictly and categorically establishes and proclaims (para. 1), that Latvia, united within the ethnographic borders (Kurzeme, Vidzeme, etc.) is self-dependent, independent, democratic, republican state; this proclamation has the nature of an international act; by this the separation of Latvia as an independent state from Russia was established

\footnotetext{
16 Akuraters, J. Latvijas valstssaturs [State content of Latvia]. Latvijas Vēstnesis. No. 12, 31.07.1920. "In the Latvian cultural environment mälēnieši were positioned as acrimonious weirdos, characterised by claims of lofty style, mixed with outright vulgarisms."

17 Ibid.
} 
(separation; see. Fiore ${ }^{18}$, Le droit international codifié, Paris 1911, 122.); by the act of separation, the territory of the separated, newly established state is ipso jure excluded from the composition of the territory of metropolis; 3) that Latvia's act of separation was formally recognised ex tunc starting already with the Peace Treaty with Russia of 11 August 1920, para. 2, 3, which establishes and sanctions Latvia's separation from Russia, within the present borders of Latvia, which comprise also Latgale; on 16 December 1920, the Latvian-Russian Peace Treaty was registered in the Secretariat of the League of Nations, by which, pursuant to para. 18, 20 of the Statute of the League of Nations of 26 April 1919, the registered treaty acquires international significance; i.e., separation of the territory of Latvia from Russia as a state; 4) that separation is the moment of origin of the newly established state and its international foundation; therefore, by Latvia's proclamation of independence its separation from the former state of Russia and Latvia's exclusion from the territory of the former Russian state occurred; this thesis is not refuted by some "Martinson's (!) precis"; if the defendant has in mind the book of well-known professor Martens ${ }^{19}$, in that case, this globally recognised scholar of international law adheres to the opinion just presented; 5) thus, the matter does not even pertain to the fact that the Latvian armed forces "had conquered" the territory of Latgale but rather that they liberated (freed) it from Bolshevist occupation; by liberating this territory its actual conditions was implemented, which corresponds to the international act of separation, already referred to; a strategic event of liberation does not have the significance of an independent international legal act, which would establish for the region of Latgale the nature of the territory of the Latvian state, as it were, only ex nunc; quite to the contrary, it had become the territory of the Latvian State already, ex tunc, by the act of separation, referred to before; 6) since Zaļmuiža civil parish is within the territory of Latvia already from 18 November 1918, pursuant to Article 1063 of the Russian Civil Law, the number of years envisaged for submitting the will to the court (the time applicable to a case where the successors are named in the will), is not applicable in the particular case; the question could only be, whether the period of one year (Art. 1063) or 10 years (Art. 1066), counting from the day of the testator's demise; 6) in this respect, if before the expiry of one year (i.e., until 6 January 1920), the region of Zaḷmuiža civil parish in Latgale had not yet been actually liberated from the Bolshevist occupational power and therefore it had been impossible to submit the will with the term indicated to the Latgale

18 Meaning: Fiore Pasquale (1837-1914). Droit international codifié et sa sanction juridique. Paris: A. Pedone, 1911. P. Fiore studied in Urbino, Pisa, and Turin, and after a period of teaching philosophy in Cremona, during which he published "Elementi di diritto pubblico constituzionale e amministrativo" (1862; "Elements of Public Constitutional and Administrative Law"), he was appointed professor of constitutional and international law at Urbino in 1863. He then occupied similar chairs at Pisa, Turin, and finally, from 1881, at Naples.

Although he was a prolific writer on most diverse range of legal topics, Fiore's international reputation rests on his writings on public and private international law. He made a sustainable contribution by realizing the need to divide international law into new categories, in his "Traité de droit pénal international et de l'extradition" (1880; "Treatise on International Criminal Law and the Law of Extradition"), and by meeting the need for a more precise statement of the law in his "Il diritto internazionale codificato e la sua sanzione giuridica" (1890; "International Law Codified and Its Legal Sanction"). See more: Fiore Pasquale. Biography. Available: https://www.britannica.com/biography/ Pasquale-Fiore [last viewed 19.02.2021].

19 I. e., the collection in 15 volumes, published from 1874 to 1909, by professor F. F. Martnes of Russia; international agreements with other countries, in parallel texts in Russian and French (Recueil des traités et conventions conclus par la Russie). See more: https://www.britannica.com/topic/Recueil-destraites-et-conventions-conclus-par-la-Russie [last viewed 19.02.2021]. 
Regional Court for confirmation, then, according to the clear text of Article 1066 of the Russian Civil Law, the will had to be submitted within 10 years; tertium non datur is not understandable, what could be the significance of Article 1066, referred to by the defendant, which deals with the term for contesting the will, whereas in the particular case the matter pertains to the request by the heiress appointed in the will to confirm the will for execution; 7) that the Court Chamber, contrary to the defendant's opinion, had full grounds to refer to the fact that no disputes were found in literature regarding application of Article 1066; the Russian Senate had renounced, long ago, its former primitive view of "the so-called theory of law" (1891, No. 62, judgement in the case of Yappa, etc.) and adopt the opposite view (e.g., in 1907, No. 18 judgement in the case of Company Neft); 8) thus, the Court Chamber has not violated the laws referred to in the defendant's cassation complaint, therefore the cassation complaint is to be dismissed as unfounded, the Senate decides to disregard the cassation complaint by the guardians of deceased Taduls Rancāns' entirety of estate Andrejs Rancāns, Meikuls Ludboržs and Antons Velikans on the basis of Section 793 of the Civil Procedure Law. ${ }^{20}$

Scholar of Law Friedrich Fromhold Martens (1845-1909), referred to in the judgement, was an outstanding personality of his time, born in Pärnu, of Baltic German origin, diplomat of the Russian Empire and specialist of international law, historian of Europe's colonial projects in Asia and Africa. Known by "the Martens' Clause", named after him, which he formulated in 1899 at the Hague Peace Conference. During 1901-1908 was repeatedly nominated for the Nobel Peace Prize, yet did not receive the award. After acquiring the degree of candidate of law, Martens continued master's, graduating in 1869 by defending the scientific work "The Right of Private Property in Wartime". He continued his education in 1870 at the Universities of Vienna, Heidelberg and Leipzig. In 1871, he became a docent at the Department of International Law at Petersburg University, but in 1872 a professor of public law at Tsarskoye Selo Lyceum. In 1873, Martens defended his doctoral dissertation "On the Office of Consul and Consular Jurisdiction in the East" and was appointed a professor extraordinary at Petersburg University, and in 1876 acquired the post of an ordinary professor. In 1874, he became the special tasks attaché of Alexander Gorchakov, the Chancellor and the Minister for Foreign Affairs of the Russian Empire. In the following years, Professor Martens achieved prominence by his writings, in particular, with the two-volume book "International Law of Civilised Nations", published in 1881 and 1882, which was released in German in 1883 (Völkerrecht. Das internationale Recht der civilisierten Nationen). From 1874 until 1909, Martens published a collection in 15 volumes about Russia’s

20 Senāta Civilā kasācijas departamenta 1929. gada spriedumi [Judgments of the Department of Civil Cassation of the Senate of 1929]. Valdības Vēstneša Pielikums, No. 160, 21.07.1937, pp. 13-14. Available: http://at.gov.lv/lv/tiesu-prakse/vesturiska-judikatura-lidz-1940gadam/senata-civilakasacijas-departamenta-spriedumi [last viewed 21.02.2021].

Explanation: In the rulings by the Department of Civil Cassation of the Latvian Senate initially its germanised denomination was used - Private Law, later - Civil Law. In the Senate's rulings, to identify it, Part III of the Collection of Local Laws was not used, but, starting with 1938, - Civil Laws of 1864 (abbreviated - CL of 1864), in difference to the Civil Law of 1937, which was abbreviated as CL (without indicating the year). At the turn of the 1930s, the abbreviation of the former Civil Law of 1864 was "L.c.l.". In this case, the use of small letters is important, because the full transcript of LCL is the Civil Law of Latgale, i.e., the Russian Civil Law, which was in force in Latgale until 1938. 
international treaties with other countries, with Russian and French parallel texts (Recueil des traités et conventions conclus par la Russie). ${ }^{21}$

Thus, within one judgement, the findings made by scholars of law of different ages meet and interact. The range of questions answered has touched upon an extensive area of law - branches of law, interdisciplinary aspects of the legal system, and systemic interpretation has been used.

Interaction between subsidiary sources in reasoning and resolution of several decisive issues of legal theory is seen also in the judgement of 16 December 1939 No. 1224 Japini Case ${ }^{22}$, in which the Court Chamber, having established that the farmstead, in the size of 14.354 ha, No. 12-12a (with hip No. 16884) located in $B$ village, Izvalta civil parish, to be divided between the participants in the case, was the estate of the latter, had granted it all in natura as not to be divided into actual shares, on the basis of para. 3, section 1324 of LCL, to the widow of the estate-leaver Tekla J., recognising the latter as being the oldest successor. The cassation complaint submitted by the person authorised by Pèteris J., a participant in the case, regarding the Court Chamber's judgment, is not worthy of attention. In it, the submitter of the cassation complaint, referring to the particularities of LCL rules on the succession order of widows and judgments of the Russian Senate No. 71/1224, 79/324 and 05/96, finds that the widow's right to the share of his estate, envisaged in Section 1148 of LCL, is not a succession right and that a widow cannot be deemed to be a heiress in the general meaning, therefore should not even be counted among the heirs envisaged in Section 1324 of LCL (allegedly, included in the part on dividing the estate). Further, the submitter of the cassation complaint, on the basis that 127 p. of 356 civil laws of Latgale Civil Law - 128, there also opponents to the opinion of the legal nature of the widow's share, finds, that there is a dispute regarding this issue. Therefore, in the particular case, on the basis of Section 31 (2) of the Transitional Provisions, CL provisions had to be applied,

21 About J. Kross's novel "Professor Martens' Departure”, published in 1983 and until now has been translated into 11 languages. The novel was published in Latvia in 2011. See: Estonian Literature Centre. Available: http://www.estlit.ee/elis/?cmd=writer\&id=49258 [last viewed 20.02.2021]. The novel by outstanding Estonian writer Jaan Kross (1920-2007) is internationally known. J. Kross studied in Tartu, in 1945 he graduated from the Faculty of Law of the Tartu University and continued working at the university as a faculty member. In 1945-1946, he was a docent at the Department of International Law. In January 1946, young docent Kross was arrested by the officers of the Soviet Commissariat for Internal Affairs (NKVD) and he was deported and sentenced to forced labour to a coal mine in Vorkuta, Komi ASSR).

See also: Akroids, P. Departure of Professor Martens. Available: https://satori.lv [last viewed 20.02.2021]. The publishing house "Atēna": “...one morning in June 1909, an Estonian, an outstanding expert of international law and secret councillor to the Czar, Professor Martens, leaves Pärnu for Peterburg. Unawares, yet having the forebodings of death, that this is his last voyage, he looks back at his life - from a pupil at a paupers' school to a politician of international renown and a real candidate for the Nobel Peace Prize, at the same time - also at the history of the end of the $19^{\text {th }} \mathrm{c}$. and the beginning of the $20^{\text {th }} \mathrm{c}$. Mostly, however, he looks into himself, examines his internal conflicts, conscience and, inescapable for a career like his, history of opportunistic relations. The author of this captivating historical novel, describing the life of the famous lawyer in service of the Czar, meticulously examines the tenet that the evil flourishes in places where decent people do nothing....

22 Senāta Civillietu kasācijas departamenta spriedumu izvilkumi. Sastādījis Senāta Civillietu kasācijas departamenta priekšsēdētājs senators O. Ozolinšs, senators R. Leitāns [Extracts from the Judgements of the Department of Cassation of Civil Cases of the Senate. Compiled by the Chairman of the Department of Cassation of Civil Cases of the Senate Senator O. Ozolinšs, Senator R. Leitāns]. Tieslietu Ministrijas Vēstneša Pielikums. No. 1., 1940. Available: http://at.gov.lv/lv/tiesu-prakse/ vesturiska-judikatura-lidz-1940gadam/senata-civila-kasacijas-departamenta-spriedumi [last viewed 20.02.2021]. 
pursuant to Section 741 of which, a widow, sharing with children, did not have the right to receive land in natura. First of all, as regards the issue whether the widow receives the share of estate envisaged in Section 1128 of LCL on the basis of the right to succession and whether the widow should be regarded as an heiress at all, then, contrary to the view expressed in the earlier judgements, referred to in the cassation complaint, in its more recent judgements, the Russian Senate had resolved this issue affirmatively (CCD, judgement 13/92, 14/21, 14/30, etc.). The correctness of this opinion, which has been approved by outstanding Russian scholars of law (see Isachenko "Russkoye grazhdanskoye sudoproizvodstvo", published in 1910, Part II, p. 350; Sinaiskis "Russkoye grazhdanskoye pravo", published in 1917./18, Part I d., p. 264, etc.) and, also, indirectly by the Latvian Senate in its CcD judgement 38/1244, is proven by the fact that Section 1148 and subsequent section of LCL, which provide that the widow is entitled to the part of the estate left, have been included in the part "on succession by law" which includes also a sub-part "On the succession procedure of spouses". Moreover, pursuant to Section 699 of LCL, the right to the respective property is acquired only in ways set out in law, however, in the respective law there is no other way of acquisition, except succession, which would envisage and regulate the acquisition by succession of the share that the widow is entitled to. Thus, a widow, from LCL perspective, generally has to be recognised as an heiress and, hence, there are no grounds whatsoever not to count her among the heirs, participating in the division, envisaged in Section 1324 of LCL, the oldest of whom, on the basis of para. 3 of this section, has a prior claim to receiving the estate, not to be divided into actual shares, in natura, understanding the oldest heir in years as such an heir (Judgement by CCD of the Russian Senate No. 78/15, etc.). This opinion, i.e., that the widow, similarly to other heirs, enjoys the priority, envisaged in para. 3 of Section $1324 \mathrm{LCL}$, to receiving estate in natura, only if she is the oldest among heirs, is shared by Isachenko (see.op.cit., p. 350) and Zavadsky (see thesis 7 on Article 1324, 1923 Tytrumov's Commentaries on the Russian Civil Law, edition of 1923). In view of the above, there cannot be rules that, in the opinion of the submitter of the cassation complaint, in the particular instance would require application of CL rules as subsidiary law. Quite to the contrary, this is exactly the case, when the current law grants to the respective heir a priority in receiving the estate leaver's estate in natura, therefore, pursuant to Section 30 (1) of the Transitional Provisions, Section 741 of CL, referred to by the submitter of the cassation complaint, is not directly applicable.

The method of systemic interpretation, doctrine of sources of law are used in the judgement, and issues of intertemporality of law are dealt with, with extensive references to the case law of the Russian Senate on similar legal issues, and to findings made by scholars of law (Isachenko, Siniaiskis, Zavadsky, Tyutromov).

\subsection{Reports by Senator M. Čakste}

Senator Mintauts Čakste is an eminent personality in the interwar Latvian Senate. Due to the insufficient number of senators, until 1934, a large backlog of cases had accumulated in the Senate's Department of Civil Cassation. The procedure for drawing up draft Senate's judgements revealed Senator Mintauts Čakste as a very capable lawyer. The Senate always had to keep in mind that lower-instance courts 
usually followed its findings, therefore the statements made in a particular case could also influence the case law in other cases. ${ }^{23}$

Examination of the findings by the Latvian Senate on the application of the Civil Law provisions ${ }^{24}$ shows that out of 368 judgements in civil cases, M. Čakste has reported and drawn up theses in 76 cases on various issues of civil law, influencing the successive legal doctrine and continuity of case law.

In the judgement of 15 July1938 on Jānis Zunde's ancillary complaint regarding the decision of 1 March 1938 by the Vice-Chairman of the Riga Regional Court on the issue of dismissing his ancillary complaint in the case with Pulcherijs Šeifers regarding 55 lats (Case No 618.), the Senate (Senator M. Čakste reporting) finds that the stamp duty should not be paid by persons, whose right to litigate in forma pauperis already had been recognised by the court rather than by persons who only wished to acquire it, also, "certificates of poverty and requests for issuing such are released from the stamp duty." 25 The Senator continues research in the context of another legal act, clarifying "certificates of poverty" and "requests for issuing such", which are unclearly defined in the previous legal act. By using elements of the method of systemic interpretation, the conclusion was reached that the plaintiff had to pay the stamp duty.

The judgement of 28 September 1938 concerned the cassation complaint by sworn advocate P. Bergis, the authorised person of the First Vidzeme Credit Union, regarding the Court Chamber's judgement on Augusts Krauklis' demand to revoke part of the decision by the general meeting in case (Case No 651.) ${ }^{26}$

The method of systemic interpretation was applied to the matter of voting procedure of a general partnership, regulation on the institution of voting in the articles of association of the general partnership was analysed, at the same time noting that the formation of a natural person's will was not linked to any articles of association. Thus, it was concluded that a general partnership, in the case of voting, must comply with the procedure set out in its articles of association, that the general partnership's articles of association envisaged repeated voting only in one instance, - i.e., pursuant to Article 81 of the articles of association, repeated voting was envisaged only in the case of election. Thus, voting on an issue included in the agenda, unless other illegalities had been committed, should take place only once. On principle, repeated voting was inadmissible. The senator explained that the legal effect of the vote was not binding for eternity since, by including the matter in the agenda repeatedly, a new decision could be made, abiding, in conjunction, by Articles 75 and 76 of the articles of association.

In the judgement of 27 October 1938 on the cassation complaint by sworn advocate N. Valters, the authorised representative of Ella Štots, regarding the

23 Čakste, A. Mintauts Čakste. Publikācijas [Mintauts Čakste. Publications]. Stockholm, 1994, p. 8.

"M. Čakste was always carefully prepared for court deliberations and the legal issues to be resolved, and his comments on draft reports were matter-of-fact. He, similarly to Senator Augusts Rumpēters, was a greater formalist than, for example, Teodors Zvejnieks, "the great campaigner for justice", who was the Chairman of the Court Chamber's Civil Department of the time."

24 Latvijas Senāta Spriedumu birojs. Latvijas Senāta atziṇas par Civillikuma normu piemērošanu (1938-1940) [Judgment Bureau of the Senate of Latvia. Statements of the Latvian Senate on the Application of Civil Law Rules (1938-1940)]. Rīga: Tiesu namu aǵentūra, 2018, pp. 104-335.

25 Senāta Civilā kasācijas departamenta 1938. gada spriedumi. Vēsturiskā judikatūra [Department of Civil Cassation of the Senate 1938 judgments. Historical case law]. Available: http://at.gov.lv/lv/ judikatura/vesturiska-judikatura-lidz-1940gadam/senata-civila-kasacijas-departamenta-spriedumi [last viewed 19.02.2021].

26 Ibid. 
decision by the Riga Regional Court in case (Case No. 1030), the methods of systemic and teleological interpretation were used.

In determining the social aim of the provision, the senator noted that the Regional Court had not taken into account the aim and had allowed payment of the alimony in several instalments, as the result of which the aim of the provision had not been reached - the mother could not in timely manner cover the expenses related to the child's maintenance, clothing, education and other necessary expenses, because, by dividing the sum into overly small parts, the mother would receive it only in 25 years, when it would no longer be possible to use it for the maintenance and education of the child who received the alimony. Systemically, viewing the legal provision in conjunction with other CPL provisions, it was concluded that the Regional Court had not taken into account Section 186 and Section 196 of the CPL, which had resulted in deficient reasoning. ${ }^{27}$

The range of legal issues to which answers were provided in the cases, on which Senator M. Čakste reported, pertained to an extensive area of law; inter alia, a child's right to maintenance, a guardian's commitments in relations with the ward, the concept of legacy, the content of a will, effects of coming into estate, divested possession, written forms of a lawful transaction, unintentional loss, prescription period, a barter contract, a maintenance contract, lease, expiry of a rental contract, application of the provisions of employment and work-performance contracts, the principal's relations, the obligation to settle accounts, and aspects in proving self-enrichment.

Nowadays, the findings made by Mintauts Čakste (as the rapporteur, member of the court's composition) allow studying historical events and the legal culture of the respective age by reading the original sources, including those published in the Collection of Rulings by the Latvian Senate, prepared by the Supreme Court ${ }^{28}$. This collection also contains the findings from the judgement by the Senate's Assembly in the disciplinary case of sworn advocate Voldemārs Zāmuels 8/1939 on 12 October 1939, materials of the case, including V. Zāmuels' explanations. Senator M. Čakste was also a member of the court's composition. In its judgement, the composition of the court decided that principal legal issues could not be examined in the procedure of supervision, because verification of the correctness of decisions by lower-instance courts on their merits, substantially, was the task of the supreme judicial instance only in the cases of the ordinary procedure of appeal. Decisions by the Council of Sworn Advocates in disciplinary cases as final were not subject to appeal and, therefore, could not be appealed against in the procedure of supervision. Permitting the contrary would mean turning the prohibition set out in the law into an empty letter and allowing the plaintiff to circumvent the law directly (the principle of abiding by laws in the name of lawful order). V. Zāmuels' complaint regarding revoking the decision by the Court Chamber was left without effect. ${ }^{29}$

The author chose to examine several judgements in cases that were adjudicated in 1940 with the participation of Senator M. Čakste. The separate opinions of

27 Senāta Civilā kasācijas departamenta 1939. gada spriedumi. Vēsturiskā judikatūra [Department of Civil Cassation of the Senate 1939 judgments. Historical case law]. Available: http://at.gov.lv/lv/ judikatura/vesturiska-judikatura-lidz-1940gadam/senata-civila-kasacijas-departamenta-spriedumi [last viewed 19.02.2021].

28 Latvijas Senāta nolēmumu atzinnas: vēsturiskais mantojums [Lessons learned from decisions of the Latvian Senate: Historical heritage]. Spriedums V. Zāmuela disciplinārlietā [Judgment in the disciplinary case of V. Zāmuels]. Rìga: Latvijas Republikas Augstākā tiesa, 2019.

29 Ibid., pp. 120-121. 
judges are added to some judgements. The separate opinion by M. Čakste and A. Rumpeters was appended to the judgement of 24 January 1940 by the Senate's Assembly, explaining why the Court Chamber's judgement should not be left in force as an additional constructive criticism of the error made by the court of the previous instance in cases of wrong interpretation of provisions, application of wrong judicature, etc.

Additional criticism of the Court Chamber's opinion relating to wrong legal reasoning appeared in M. Čakste's separate opinion in the Assembly's case No. 39/31, in which he underscored that it had been rightly noted in the cassation complaint that the Court Chamber had operated with a negative circumstance, which did not have the force of evidence. The Court Chamber's opinion regarding the existence of novation could not be recognised as having sufficient and legally correct reasoning. ${ }^{30}$

In those judgements, where M. Čakste has been the rapporteur on the case, his legal reasoning is captivating. For example, in a case regarding calculation of the term for cassation complaint in connection with the fact when the person had become informed about the Court Chamber's judgement. It is concluded that the failure to issue summons to the court hearing cannot be the cause either for submitting the planned extraordinary appeal nor for submitting the planned extraordinary cassation in connection with the valid legal regulation. If the summons had not been issued for the court hearing of the first instance, where the judgement had been delivered, such judgement should be appealed against by an appeals complaint. ${ }^{31}$ In these cases, references to doctrine (Vladimirs Bukovskis' work) was assessed. This proves that civil law has a more pronounced succession in connection with interactions between practice and legal science. ${ }^{32}$

In the judgement in the Senate's case relating to the aspect in determining the jurisdiction of a case of 14 March 1940, at the open assembly of the Civil Cassation Department it was concluded - if none of the circumstances, which, in accordance with the legal regulation, were decisive for the jurisdiction of the case was present, the plaintiff himself could determine the jurisdiction for the case, using his own discretion. ${ }^{33}$

On 26 September 1940, the Senate's Civil Cassation Department reviewed case No. 763 on the cassation complaint by the authorised representative of the Latvian Evangelic Lutheran Church regarding the decision of 13 June 1940 by the Head of Riga-Valmiera Land Register Department of the Court Chamber concerning corroboration of immovable property in the name of the Evangelic Lutheran Church, because St. Peter's Evangelic Lutheran German Congregation had dissolved itself. Senators O. Ozoliņš, J. Grots and M. Čakste decided that it could be concluded from Article 48 of the Constitution of the Church that the Church continued to exist and retained its property until a new congregation was established, the

30 In this case, the joint existence of the new and the old liability is entirely possible and, even more, the new liability in connection with the issuing of bills of exchange cannot be presumed as being novation (note "v" at CL Section 3586, in Bukovskis' edition). Our Senate, likewise, has constantly recognised that the issuing of a bill of exchange is not a payment "in solutum", but a postponed payment "solvendi causa" (CCD of the Senate, judgement 31/881 and others). LNA LSHA, 1535. f., 8. apraksts [description] (hereafter - apr.), 267. lieta [file] (hereafter - 1.).

31 LNA LSHA, 1535. f., 8. apr., 329. 1.

32 See more: Latvijas Senāta nolēmumu atzinas: vēsturiskais mantojums [Lessons learned from decisions of the Latvian Senate: Historical heritage]. Ievads [Introduction], p. 7.

33 LNA LSHA, 1535. f., 8. apr., 306. 1. 
right to use the church property was transferred to the Central Board. Thus, the Constitution of the Church had envisaged that the church as a legal person could exist also after a congregation was dissolved. ${ }^{34}$ This legal aspect remains relevant today in connection with the issues of returning property to religious organisations if new congregations are established, which could cause disputes regarding the title to property.

Most often, M. Čakste outlined a legal problem in the judge's separate opinion in connection with wrong reasoning in using the findings from case law and doctrine, drawing attention to legal uncertainties and, possibly, insufficient discussions among the court's composition.

As a convinced democrat and defender of parliamentary order, he could not reconcile himself to the coup of 15 May 1934 and the authoritarian regime of the time in Latvia, which he did not hide in private conversations with his colleagues. However, the issue of the legality or illegality of the said regime was never discussed at the hearings of the Senate's Court or Assembly. ${ }^{35}$ Throughout World War II, he believed in the victory of England and its allies but also hoped that this victory would bring Latvia freedom again. ${ }^{36} \mathrm{M}$. Čakste sought to restore the functioning of Latvian courts during the period of German occupation. ${ }^{37}$ In exile, M. Čakste was a recognised scholar of law in the area of international law, and wrote an article about the international legal concept of the Soviet Union, which was published in a prominent American legal journal (1949). Mintauts Čakste also has analysed the agrarian structure of the Soviet Latvia and other legal issues. The article "Das persönliche Eigentum der Sowjetbürger" was published by Dietrich André Loeber in the magazine dedicated to the Soviet law that he edited. M. Čakste is the author of 16 analytical research articles on international law. ${ }^{38}$

When reading and assessing the findings of the Latvian Senate, it is worth keeping in mind that the legal regulation has changed since the time when they have been created. However, this does not affect the understanding of law, based on the principles of a democratic state governed by the rule of law, and legal thinking, which the Latvian Senators and employees of the Bureau of Judgements held during the interwar period on what it should be like among lawyers of contemporary

34 LNA LSHA, 1535. f., 12.III apr., 1834. 1.

35 Čakste, A. Mintauts Čakste. Publikācijas [Mintauts Čakste. Publications], p. 9.

36 Ibid., p. 9. "A. Rumpēters, while in exile, had heard about M. Čakste that, in case of disputes, it was impossible to reach an understanding and a compromise with him. To a certain extent, this could be applicable also to his social and political activities. Convinced about the correctness of his opinion, Cakste defended it strictly at the Senate's debates and, when outvoted, sometimes wrote his separate opinion. Others, perhaps, did it less frequently. M. Čakste was a man of principle."

37 Čakste, A. Mintauts Čakste. Publikācijas [Mintauts Čakste. Publications], p. 19.

38 Apse, D. Mintauta Čakstes zinātniskais mantojums. Tā nozīme Latvijas valstsgribas turpinātỉbā [Scientific Legacy of Mintauts Čakste. Its Standing in Continuity of Will for Latvian Statehood]. In: LU Juridiskās fakultātes 7. starptautiskās zinātniskās konferences rakstu krājums. Tiesību zinātnes uzdevumi, nozīme un nākotne tiesību sistēmās I. Legal Science: Functions, Significance and Future in Legal Systems I. The $7^{\text {th }}$ International Scientific Conference of the Faculty of Law of the University of Latvia.] Rīga: LU Akadēmiskais apgāds, 2019, p. 474. Available: https://www.apgads.lu.lv/fileadmin/ user_upload/lu_portal/apgads/PDF/Juridiskas-konferences/LUJFZK-7-2019/iscflul-7_2019_Tieszin-uzd-noz-nak.pdf. [last viewed 25.02.2021]. 
Latvia, inter alia, in applying the Civil Law provisions. ${ }^{39}$ The examples and legal institutions, described in the conditions of the contemporary legal system, mostly have similar regulation and could be useful in developing judicature on a certain matter. The interaction of subsidiary sources, in particular, using the findings from doctrine (V. Bukovskis, V. Sinaiskis, etc.) builds bridges across ages and promotes uniform case law and continuity in the understanding of law. The area of Latvian law is inconceivable without the studies, monographs, articles by A. Loeber, M. Čakste and other outstanding scientists and practitioners, as well as the findings from case law. They will inspire many more future generations of lawyers.

\section{Summary}

1. The scientific contribution by Senators A. Loeber and M. Čakste is universal and significant in the context of European and global thinking. Notwithstanding the circumstances, they remained loyal to democratic Latvia. Their findings develop the Latvian legal system, in particular, in the last stage of the interwar period, reveal deep understanding of most diverse issues of private law, etc., criticising the previous faulty legal reasoning.

2. The range of legal issues to which answers were provided pertains to an extensive area of law - branches of law, interdisciplinary aspects of the legal system, revealing the good command they had of the problematic issues of all branches of law. The protected legal benefit and assessment of values, as well as the legal methodology for correct application of law are disclosed in convincing reasoning. This has had a lasting significance in the correct application of civil law and further development of international law.

3. The findings made by personalities - Senators A. Loeber and M. Čakste in the judgements by the interwar Latvian Senate, the findings of other outstanding scholars of law of other ages and the findings from doctrine used in their interaction build bridges across ages and promote the development of united case law and succession in the understanding of law. Findings these sterling achievements - continue their path and have brought into the Latvian legal thinking the breath and quality of the world.

\section{Sources}

\section{Bibliography}

1. Akuraters, J. Latvijas valstssaturs [State content of Latvia]. Latvijas Vēstnesis, No. 12, 31.07.1920.

2. Apse, D. Tiesu prakse un Latvijas Senāta Administratīvais departaments (1918-1940) [Judicial practice and the Administrative Department of the Latvian Senate (1918-1940)]. In: Tiesu prakses veidošana. LU Zinātniskie raksti [Development of court practice. LU scientific articles]. Edited by Dr. habil. iur. prof. Melkisis, E. Riga: Latvijas Universitāte, 2001, pp. 68-101.

3. Apse, D. Mintauta Čakstes zinātniskais mantojums. Tā nozīme Latvijas valstsgribas turpinātībā [Scientific Legacy of Mintauts Čakste. Its Standing in Continuity of Will for Latvian Statehood]. In: LU Juridiskās fakultātes 7. starptautiskās zinātniskās konferences rakstu krājums. Tiesību zinātnes uzdevumi, nozīme un nākotne tiesību sistēmās I. [The $7^{\text {th }}$ International Scientific Conference of the Faculty of Law of the University of Latvia Legal Science: Functions, Significance and Future in Legal Systems I 16-18 October 2019, Riga. Collected conference papers]. Riga: LU

39 Terihova, S. Par grāmatā apkopoto Latvijas Senāta atziņu izmantošanu. Senāta Spriedumu birojs. Latvijas Senāta atziņas par Civillikuma normu piemèrošanu (1938-1940) [On the use of the conclusions of the Latvian Senate in the book. Judgment Bureau of the Senate of Latvia. Statements of the Latvian Senate on the Application of Civil Law Rules (1938-1940)]. Rìga: Tiesu namu aǵentūra, 2018, p. 95. 
Akadēmiskais apgāds, 2019, p. 474. Available: https://www.apgads.lu.lv/fileadmin/user_upload/ lu_portal/apgads/PDF/Juridiskas-konferences/LUJFZK-7-2019/iscflul-7_2019_Ties-zin-uzdnoz-nak.pdf [last viewed 25.02.2021].

4. Apsitis, R. Par Latvijas pamatu vīriem. Runas. Raksti. Referāti [About Men at Latvia’s Foundations. Speeches. Writings. Reports]. Latvijas Vēstnesis, No. 11/12, 16.01.1998. Available: https://www. vestnesis.lv/ta/id/31202 [last viewed 20.02.2021].

5. Čakste, A. Mintauts Čakste. Publikācijas [Mintauts Čakste. Publications]. Stokholma, 1994, p. 8.

6. Dišlers, K., Dunsdorfs, E. Tautsaimniecības un tiesību zinātnu fakultāte [Faculty of Economics and Law]. In: Latvijas Universitāte divdesmit gados. 1919-1939. I dal̦a. Vēsturiskas un statistiskas ziṇas par Universitāti un tās fakultātēm [University of Latvia in twenty years. 1919-1939. Part I. Historical and statistical information about the University and its faculties]. Riga: Latvijas Universitāte, 1939, p. 748.

7. Melkisisis, E. Attīstỉbas tendences dažos tiesību teorijas un prakses jautājumos. Par precedentu un tiesu prakses veidošanu. Latvijas tiesiskās sistēmas ceḷ̌s uz demokrātisku tiesisku valsti. Rakstu krājums [Development tendencies in some issues of legal theory and practice. On the formation of precedents and case law. The path of the Latvian legal system to a democratic state governed by the rule of law. Collection of articles]. Rīga: Tiesu namu aǵentūra, 2014, p. 164.

8. Melkisisis, E. Par tiesu prakses vienotỉbu [On Unity of Court Practice]. In: Tiesu prakses veidošana. LU Raksti. [Development of court practice. UL scientific articles]. Edited by Dr. habil. iur. prof. Melķisis, E. Rīga: Latvijas Universitāte, 2001, p. 10.

9. Latvijas Senāta nolēmumu atziņas: vēsturiskais mantojums [Lessons learned from decisions of the Latvian Senate: Historical heritage]. Rìga: Latvijas Republikas Augstākā tiesa, 2019.

10. Latvijas Senāta Spriedumu birojs. Latvijas Senāta atziṇas par Civillikuma normu piemērošanu (1938-1940) [Judgment Bureau of the Senate of Latvia. Statements of the Latvian Senate on the Application of Civil Law Rules (1938-1940)]. Rīga: Tiesu namu aǵentūra, 2018, pp. 104-335.

11. Latvijas Senāta spriedumi (1918-1940). Faksimilizdevums [Judgments of the Latvian Senate (1918-1940). Facsimile edition]. Riga: Supreme Court of the Republic of Latvia, Senator August Loeber Foundation, 1997-1998.

12. Rādītāji Latvijas Senāta spriedumu krājumiem [Indicators for the collections of judgments of the Latvian Senate]. Edited by Loeber, D. A. Rīga: D. A. Lēbers, 1997.

13. Latvijas Universitāte divdesmit gados. 1919-1939. II dal̦a. Mācības spēku biogrāfijas un bibliogrāfija [University of Latvia in twenty years. 1919-1939. II part. Biographies and bibliography of teaching staff]. Rìga: Latvijas Universitāte, 1939, p. 550.

14. Latvijas Universitāte divdesmit gados. 1919-1939. I daḷa. Vēsturiskas un statistiskas ziṇas par Universitāti un tās fakultātēm [University of Latvia in twenty years. 1919-1939. Part I. Historical and statistical information about the University and its faculties]. Riga: Latvijas Universitāte, 1939, pp. 749-750.

15. Terihova, S. Par grāmatā apkopoto Latvijas Senāta atziņu izmantošanu. Senāta Spriedumu birojs. Latvijas Senāta atziņas par Civillikuma normu piemērošanu (1938-1940) [On the use of the conclusions of the Latvian Senate in the book. Judgment Bureau of the Senate of Latvia. Statements of the Latvian Senate on the Application of Civil Law Rules (1938-1940)]. Riga: Tiesu namu aǵentūra, 2018, p. 95.

16. Torgāns, $K$. Tiesību principu, likumu un zinātnes atziṇu loma civiltiesisku strīdu risināšanā [The Role of Legal Principles, Laws and Scientific Findings in Resolving Civil Disputes]. Jurista Vārds, No. 49, 04.12.2018, p. 13.

\section{Decisions of the Senate of the Republic of Latvia and Judges' Particular Thoughts (Interwar)}

1. Augstākā tiesa. Vēsturiskā judikatūra [Supreme Court. Historical case law]. Available: http:// at.gov.lv/lv/judikatura/vesturiska-judikatura-lidz-1940gadam [last viewed 18.02.2021].

2. Latvijas Senāta Civilā kasācijas departamenta 1921. gada 8. decembra spriedums lietā Nr. 188 [Judgment of the Civil Cassation Department of the Latvian Senate of 8 December 1921 in case No. 188]. In: Konradi, F., Valters, A. Izvilkums no Latvijas Senāta Civilā kasācijas departamenta spriedumiem. 1919.-1925. gada jülijs. II izdevums [Extract from the Judgement of the Department of Civil Cassation of the Latvian Senate. July 1919-1925. Edition II]. Latvian National Archives, Latvian State Historical Archive, fund 1535, p. 142. Available: http://at.gov.lv/lv/tiesu-prakse/ vesturiska-judikatura-lidz-1940gadam/senata-civila-kasacijas-departamenta-spriedumi [last viewed 18.02.2021].

3. Senāta Civilā kasācijas departamenta 1929. gada spriedumi [Judgments of the Department of Civil Cassation of the Senate of 1929]. Valdības Vēstneša Pielikums, No. 160, 21.07. 1937, 
pp. 13-14. Available: http://at.gov.lv/lv/tiesu-prakse/vesturiska-judikatura-lidz-1940gadam/ senata-civila-kasacijas-departamenta-spriedumi [last viewed 21.02.2021].

4. Senāta Civillietu kasācijas departamenta spriedumu izvilkumi. Sastādījis Senāta Civillietu kasācijas departamenta priekšsēdētājs senators O. Ozoliņš, senators R. Leitāns [Extracts from the Judgements of the Department of Cassation of Civil Cases of the Senate. Compiled by the Chairman of the Department of Cassation of Civil Cases of the Senate Senator O. Ozoliņš, Senator R. Leitāns]. Tieslietu Ministrijas Vēstneša Pielikums, No 1, 1940. Available: http://at.gov. lv/lv/tiesu-prakse/vesturiska-judikatura-lidz-1940gadam/senata-civila-kasacijas-departamentaspriedumi [last viewed 20.02.2021].

5. Senāta Civilā kasācijas departamenta 1938. gada spriedumi. Vēsturiskā judikatūra [Department of Civil Cassation of the Senate 1938 judgments. Historical case law]. Available: http://at.gov. lv/lv/judikatura/vesturiska-judikatura-lidz-1940gadam/senata-civila-kasacijas-departamentaspriedumi [last viewed 19.02.2021].

6. Senāta Civilā kasācijas departamenta 1939. gada spriedumi. Vēsturiskā judikatūra [Department of Civil Cassation of the Senate 1939 judgments. Historical case law]. Available: http://at.gov. lv/lv/judikatura/vesturiska-judikatura-lidz-1940gadam/senata-civila-kasacijas-departamentaspriedumi [last viewed 19.02.2021].

\section{Archival Documents}

1. Latvian National Archives, Latvian State Historical Archive, fund 1535, description, 8, file 318.

2. Latvian National Archives, Latvian State Historical Archive, fund 1535, description 8, file 267.

3. Latvian National Archives, Latvian State Historical Archive, fund 1535, description 8, file 329.

4. Latvian National Archives, Latvian State Historical Archive, fund 1535, description 8, file 306.

5. Latvian National Archives, Latvian State Historical Archive, fund 1535, description 12 III, file 1834.

\section{Other Sources}

1. Profesora Martensa aizbraukšana [Departure of Professor Martens]. Available: https://satori.lv/ book/profesora-martensa-aizbrauksana [last viewed 20.02.2021].

2. Fiore Pasquale. Biography. Available: https://www.britannica.com/biography/Pasquale-Fiore [last viewed 19.02.2021].

3. Jaan Kross [About J. Cross's novel "Professor Martens' Departure"]. Estonian Literature Centre. Available: http://www.estlit.ee/elis/?cmd=writer\&id=49258 [last viewed 20.02.2021].

4. Tiesību zinātṇu pētniecības institūts [Law Research Institute]. Available: https://tzpi.lu.lv/pirmaisneatkaribas-laiks/tiesu-prakse/ [last viewed 18.02.2021].

5. Recueil des traités et conventions conclus par la Russie [[From 1874 to 1909, a collection of 15 volumes published by Professor F. F. Martens on Russia's international agreements with other countries in parallel in Russian and French]. Available: https://www.britannica.com/topic/Recueil-des-traiteset-conventions-conclus-par-la-Russie [last viewed 19.02.2021]. 